\title{
頸部廓清術後の合併症一Chy lothoraxの一例
}

\author{
○青柳 充雄・富山 紘彦・浅野 毅 \\ 木田 亮紀 \\ (日本大学耳鼻咽喉科)
}

頸部邡清術後に生じる乳ビ胸の合併症は非常に 稀であります。我々は、左頸部廓清術後、乳ビ胸 を来たした一症例を経験し、その成因、診断、そ して治療につけて検討致しました。

症例怡癌有する62才の女性で、左頸部に転 移を来たしており、舌の原発巣は照射と化学療法 の併用でコントロールされましたが、左転移性頸 部リンパ節が消失せボ、左頸部廓清術を施行いた しました。第 2 病日、咳嗽、呼吸困難を来たしま したので、胸部レントグンをとりましたととろ、 左側の胸水貯留が認められまして。そてで、術中 に乳ビの漏出を認めたとと、発熱がないなど、ま た胸腔穿刺により乳白色の液体が得られたてとよ り、乳ビ胸と診断いたしました。ところで、乳ビ の基本的細胞はリンパ球であり、細菌学的には無 菌、蛋白は約 $3.2 \mathrm{~g} / \mathrm{d} \ell$ 、脂肪は 500 $3000 \mathrm{mg} /$ $d \ell 、 リ$ バル反応は陽性、P Hは7.0以上であり ますので、以上の検査を施行いたしましたとてろ、 我々の症例も侄低しれらに合致しておりました。 また、血液検査でもリンパ球の減少、蛋白及びア ルプミンの減少、 $\mathrm{Ca}$ の減少が認められました。

乳ビ胸の成因でありますが、第1亿術創閉鎖後、 再び乳ビの漏出があること、第 2 亿持続ドレナー シを開始した後、左鎖骨上裔の乳ビ漏のある部分 に死腔を形成すると、そこに乳ビ腫が発生し、乳 ビが压により縱隔を経て胸腔へ浸透するととによ り乳ビ胸が生じます。

治療でありますが、全身的には低蛋白血症、電 解質のアンバランスを考虑した栄養が必要となり ます。それとはアミノ酸製剤、ビタミン及びプラ スマネートを加えた経静脈栄養が、medium一䋕 chain triglyceride 即ち、MCT の経口摄 取がすすめられます。我々の症例では、まず禁食 とし、ビタミン、プラスマネートを投与し、経口 的に低脂高タンパク及び高含水炭素の食慨を摄取 させ、電解質のアンバランス及び低アルプミン血 症の改善をみました。また、咳嗽や下肢の運動に より胸管リンパ流の増加を来たしますので、鎮陔 剤の投与及びベッド上安静が必要となります。゚

局所的には、まずドレナーシ（頸部術創）及び 王迫包带により乳ビ漏出部位の死腔をなくすとと 几務めます。我々は、この方法で乳ビ漏をコント ロールし得ましたが、無効の場合には、術創を再 開放し結紫あるいは王迫が必要となります。また、 乳ビ胸に対しては胸腔穿刺を行をいますが、以上 述へた方法では改善をみない重篤な場合には th一 oracotomyによる胸管の thoracic-portion の直接結禁が必要となります。

\section{嵔問＼cjkstart森満（宮医大）}

chylusの漏出を確認する為に術前にバター を投与しておくと良く分百のですが、何か、特 別な配慮をしておられますか。或いは万一損傷 した時の対策などありましたら御教え下さい。 答青柳充雄 (日大耳鼻科)

乳ビ漏の予防について

(1)術前 6 時間前にバター等の脂肪食を与える。 (2)術中にインジゴカルミン等の色素を注入して、 それが頸部術創に漏れてくるかを確認する方法 (3)術中に麻酔梁度を浅くして胸腔内圧に伴ら胸 管リンパ流の増大を起として、それを確認する 方法。

などである。 